удК 332.142:332.146

\title{
РОЗВИТОК МІЖРЕГІОНАЛЬНОГО ПАРТНЕРСТВА В РАМКАХ ФОРМУВАННЯ СТРАТЕГІЇ СМАРТСПЕЦІАЛІЗАЦІї
}

\section{DEVELOPMENT OF INTERREGIONAL PARTNERSHIP WITHIN THE FRAMEWORK OF A SMART SPECIALISATION STRATEGY}

\author{
Швець Наталія Вячеславівна \\ кандидат економічних наук, доцент, \\ Інститут економіки промисловості НАН України \\ ORCID: https://orcid.org/0000-0003-1215-2397 \\ Shvets Nataliia \\ Institute of Industrial Economics of the NAS of Ukraine
}

\begin{abstract}
Стаття розкриває науково-практичні питання залучення потенціалу партнерської взаємодії у процес фрормування регіональних стратегій смартспеціалізації. У рамках концепції смартспеціалізації виділено три рівні партнерства (регіональний, міжрегіональний та наднаціональний), що враховують ієрархічний порядок задіяних інноваційних екосистем і синхронізацію різнорівневих стратегій смартспеціалізації. Основний акцент зроблено на міжрегіональному партнерстві, значущість якого зростає 3 концептуальним та емпіричним розвитком розумного стратегування. Проаналізовано тенденції застосування співробітництва регіонами ЄС, стимульованого регіональною смартспеціалізацією. Зроблено висновок про поширення через цифровізацію платорормного партнерства та потенційне зростання конкуренції між регіонами-претендентами на євроспівробітництво.

Ключові слова: смартспеціалізація, партнерство, міжрегіональне співробітництво, регіональний розвиток.
\end{abstract}

Статья раскрывает научно-практические вопросы привлечения потенциала партнерского взаимодействия в процесс формирования региональных стратегий смарт-специализации. В рамках концепции смартспециализации выделены три уровня партнерства (региональный, межрегиональный и наднациональный), которые учитывают иерархический порядок вовлеченных инновационных экосистем и синхронизацию разноуровневых стратегий смарт-специализации. Основной акцент сделан на межрегиональном партнерстве, значимость которого растет с концептуальным и эмпирическим развитием разумного стратегирования. Проанализированы тенденции использования сотрудничества регионами ЕС, стимулированного региональной смарт-специализацией. Сделан вывод о распространении в результате цифровизации платфрорменного партнерства и потенциальном росте конкуренции между регионами-претендентами на евро-сотрудничество.

Ключевые слова: смарт-специализация, партнерство, межрегиональное сотрудничество, региональное развитие.

The article is devoted to topical scientific and practical issues of attracting the potential of partnership interaction in the processes of formation and implementation of regional strategies for smart specialisation. The purpose of the article is to clarify the role, typology of partnership in the framework of the formation of smart specialisation strategies by regions and to analyze the development trends of interregional and cross-border cooperation. The methodological basis of the research is the concept of smart specialisation and its development in terms of thematic interregional partnerships. To achieve this goal, dialectical, logical and systemic scientific methods were used. In the context of the concept of smart specialisation three levels of partnership are identified namely regional interregional and supranational. These levels take into account the hierarchical order of innovation ecosystems that are involved in smart specialisation, as well as the targeted synchronization of different smart specialisation strategies. It was emphasized that the organisational and legal basis for the interaction of stakeholders at the local level within the framework of the smart specialisation strategy can be formed by public-private partnerships. The main emphasis is made on interregional partnership, the importance of which grows with the conceptual and empirical development of smart strategizing. Trends in the use of cooperation between the EU regions stimulated by regional smart specialisation are analyzed. The development of a thematic partnership on the smart specialisation platform, which is supported by the European Commission, was considered. It is concluded that thematic digital platforms form a set of 
innovation networks that combine the priorities of smart specialisation in different regions and link regional innovation ecosystems. The conclusion is made about the future growth of competition between the regions-applicants for Euro cooperation. Therefore, when planning cooperation with the EU regions Ukrainian regional smart specialisation teams need to carefully analyze the existing competitive advantages and work on their further development.

Keywords: smart specialisation, partnership, interregional cooperation, regional development.

Постановка проблеми. Практика стратегічного менеджменту успішних компаній світу ще в 90-х рр. XX ст. продемонструвала, що в умовах глобалізації і динамічного ринкового середовища досягти стійких конкурентних позицій на ринку можливо через розвиток стратегічного партнерства. Сорокусоване і взаємовигідне співробітництво дозволяє значно заощаджувати час та ресурси на шляху до визначених довгострокових бізнес-цілей. Сьогодні переваги партнерської взаємодії очевидні не тільки на мікро-, а й на мезо- і макроекономічному рівнях.

В умовах сучасної транссоормації системи управління регіональним розвитком, обумовленої децентралізацією влади, актуалізуються науково-прикладні питання розвитку різнопланового співробітництва як всередині певних територіальних утворень, так і за їх межами.

Аналіз останніх досліджень і публікацій. Партнерство в контексті регіонального розвитку опрацьовується вітчизняними вченими у різних аспектах. Автори робіт [1-5] значну увагу приділяють вивченню закордонного досвіду та формуванню теоретичних основ і розробленню практичних рекомендацій щодо впровадження в практику українських регіонів публічно-приватного партнерства (ППП).

Активізація внутрішніх інтеграційних процесів в Україні розглядається як шлях подолання диспропорцій у регіональному розвитку. 3 такою метою фрахівцями [6-8] опрацьовуються теоретико-методологічні засади планування співробітництва територіальних громад та стратегування міжрегіонального економічного партнерства всередині країни.

У рамках євроінтеграційних процесів українські регіони отримали широкі можливості для налагодження та розвитку партнерських відносин з регіонами країн $Є С$. Сприяти реалізації даних намірів можуть регіональні стратегіï смартспеціалізації (Strategy for Smart Specialization - S3), фоормування яких оopiційно розпочато в Україні у 2019 р.

Підхід S3 - це європейська методологія [9], яка передбачає використання регіонами, перш за все, внутрішнього потенціалу для визначення інноваційних напрямів економічного зростання через колаборацію місцевих бізнесу, науки, влади і громадськості. Результативність фоункціонування регіональних інноваційних екосистем залежить від продуктивних комунікацій між провідними стейкхолдерами, що передбачає обмін знаннями, технологіями і досвідом, розробку спільного бачення можливостей розвитку вже існуючих або нових виробництв та концентрацію ресурсів на узгоджених пріоритетах [10].

3 концептуальним розвитком методології S3 [11; 12] все більшої значущості набуває інтеграційна компонента стратегії смартспеціалізації, яка покликана підсилити регіональні ресурсно-компетенційні можливості створення інновацій та підвищити ефективність такої діяльності. Даний напрям зараз активно досліджується українськими вченими. Так, у роботах $[5 ; 13 ; 14]$ розглядаються науково-практичні питання поглиблення європартнерства у дослідницькій та інноваційній сорерах на засадах смартспеціалізації. Автори підкреслюють необхідність розвитку національних інноваційних екосистем через налагодження стійких партнерських відносин 3 європейськими країнами/регіонами, міжнародними організаціями, університетами, науково-дослідними інституціями та підприємницькими структурами.

Отже, результати літературного аналізу відображають зростання у наукових колах інтересу до теми партнерства в контексті S3, що свідчить про актуальність даного напряму досліджень, зокрема 3 точки зору прискорення впровадження на різних економічних рівнях механізмів партнерської взаємодії задля успішної реалізації політики розумного зростання. Враховуючи динамічний концептуальний та емпіричний розвиток смартстратегування, зазначена тематика потребує подальшого поглибленого вивчення.

Мета статті полягає в уточненні ролі, типології партнерства і визначенні тенденцій його розвитку у міжрегіональному, транскордонному напрямі в рамках фрормування регіонами стратегій смартспеціалізації.

Основний матеріал дослідження. Згідно 3 європейською методологією смартспеціалізації, взаємодія, що зароджується в межах регіональної інноваційної екосистеми між бізнесом, науковою сорерою, владними струк- 
турами і громадськістю, виступає рушійною силою смартспеціалізації. Водночас важливо розуміти, що співпраця основних акторів на рівні регіону має бути підсилена ефективною комунікацією з іншими регіональними, національними та транскордонними інноваційними екосистемами [15]. Тобто в рамках концепції S3 треба розглядати фрормування та розвиток партнерських відносин як всередині регіону, так і за його межами.

Зазначимо, що поняття «партнерство», згідно 3 його тлумаченням на порталі української мови та культури «Словник UA» [16], включає декілька характерних ознак, що розкривають його сутність. Зокрема, під ним розуміють: узгодженість, злагодженість дій; «... взаємні відносини, основані на взаємовигідності та рівноправності...»; фрорму співробітництва; добровільну співпрацю двох або кількох суб'єктів. Водночас припускається, що партнерство може утворюватися між срізичними, юридичними особами, а також за участю великих суб'єктів, як-от регіонів та країн.

У рамках концепції S3 можлива поява різних за організацією взаємодії моделей партнерств. Так, партнерські відносини можуть фрормуватися на основі «потрійної спіралі», що передбачає співробітництво в системі «держава - наука - бізнес». Саме така модель була закладена в первісний варіант концепції смартспеціалізації, яка пізніше з додаванням громадського сектору трансформувалась у модель «чотирьох спіралей». Присутність громадськості, за задумом розробників концепції [9], має запобігати лобіюванню інтересів окремих регіональних стейкхолдерів на шкоду інтересів решти суспільства.

Р. Хассінк і Х. Гонг [17], розглядаючи смартспеціалізацію як частину регіональної інноваційної політики, зазначають, що співробітництво утворюється між університетами, держав- ними дослідницькими установами та підприємствами. Також автори виділяють два види співробітництва всередині підприємницького сектору: вертикальне - між МСП і великими підприємствами та горизонтальне - між МСП.

У контексті створення організаційно-правової основи взаємодії стейкхолдерів на засадах S3 на місцевому рівні найбільш прийнятною фрормою $€$ публічно-приватне партнерство. ППП, на думку вчених [1-5], є перспективним для активізації інноваційної діяльності видом угоди між державою, бізнесом та громадськістю, що вибудовується на інтересах та вигодах кожної сторони. Характеристику зацікавленості секторальних учасників у публічно-приватному партнерстві представлено в табл. 1.

Звуженим варіантом подібної ППП взаємодії є державно-приватне партнерство, яке не розглядає участь так званого «третього сектору» влади - громадського суспільства. Організаційно-правові засади в нашій країні законодавчо визначені тільки для такого виду партнерства.

Закон України «Про державно-приватне партнерство» трактує його як «співробітництво між державою Україна, Автономною Республікою Крим, територіальними громадами в особі відповідних державних органів, що згідно із Законом України «Про управління об'єктами державної власності» здійснюють управління об'єктами державної власності, органів місцевого самоврядування, Національною академією наук України, національних галузевих академій наук (державних партнерів) та юридичними особами, крім державних та комунальних підприємств, установ, організацій (приватних партнерів), що здійснюється на основі договору в порядку, встановленому цим Законом та іншими законодавчими актами, та відповідає ознакам

Характеристика зацікавленості учасників публічно-приватного партнерства

Таблиця 1

\begin{tabular}{|l|l|}
\hline \multicolumn{1}{c|}{$\begin{array}{c}\text { Секторальні } \\
\text { учасники }\end{array}$} & \multicolumn{1}{|c|}{ Характер зацікавленості } \\
\hline Приватний сектор & $\begin{array}{l}\text { Зниження підприємницьких ризиків, отримання гарантованого } \\
\text { довгострокового доходу, розширення діяльності завдяки отриманню } \\
\text { від держави гарантій і пресреренцій. }\end{array}$ \\
\hline Державний сектор & $\begin{array}{l}\text { Залучення приватних інвестицій для вирішення соціально-економічних } \\
\text { завдань розвитку і відповідно зниження навантаження на державний } \\
\text { та місцеві бюджети. }\end{array}$ \\
\hline Громадськість & $\begin{array}{l}\text { Прозорість економічної діяльності на благо суспільних інтересів } \\
\text { через участь громадськості у процесах розробки і реалізації спільних } \\
\text { проєктів, програм. }\end{array}$ \\
\hline
\end{tabular}

Джерело: складено за даними [1; 3; 4; 5, с. 216-217] 
державно-приватного партнерства, визначеним цим Законом». 3 даного визначення виходить, що чинним законодавством встановлені можливості започаткування партнерських відносин на основі неповної «потрійної спіралі», до якої не включається університетська наука. Обмежує використання ППП з метою інноваційного розвитку економіки й визначений у статті 4 перелік сорер застосування державно-приватного партнерства, який не містить наукову та технічну діяльність. Зазначені прогалини в законодавстві можуть стати бар'єром для подальшої імплементації підходу смартспеціалізації в Україні у частині створення інституційних умов для активізації інноваційної діяльності на основі ППП із залученням, зокрема університетів.

Не менш важливим для досягнення цілей S3, a caме структурної модернізації і підвищення конкурентоспроможності регіональних економік, $€$ започаткування і розвиток партнерських взаємин за межами окремих регіонів. Зовнішнє партнерство (рис. 1) може утворюватися на міжрегіональному та наднаціональному рівнях, що відповідно супроводжується взаємодією інноваційних екосистем вищого порядку та забезпечує взаємодоповненість і взаємопідсилення регіональних і національних стратегій смартспеціалізації.
Згідно з методологією S3, міжрегіональне та транснаціональне співробітництво розглядається європейськими фахівцями [11, с. 79] як один з ключових складників стратегії смартспеціалізації. Експерти зазначають, що відкритість стратегій смартспеціалізації та їх спрямованість назовні дають регіонам доступ до широких бізнес- та знаннєвих мереж, дозволяють зміцнити свій дослідницький потенціал, вийти на інші ринки, розширити підприємницькі можливості, посилити власні сильні сторони, інтегруватися у глобальні ланцюги доданої вартості та наростити інвестиції у регіональні економіки.

У 2013 р. десятьма європейськими регіонами було започатковано ініціативу Авангард (Vanguard Initiative) [18] з впровадження пілотних проєктів міжрегіонального партнерства на засадаx S3. Отримані результати продемонстрували, що смартспеціалізація та кластерна міжрегіональна співпраця сприяють новому промисловому зростанню. Підтвердженням успіху та подальших перспектив даної ініціативи став запуск Європейською комісією тематичних платформ смартспеціалізації (S3P), що відбувся на конореренції Smart Regions у червні 2016 р.

На сьогодні «Авангард» - це альянс 39 регіонів Європи, які прагнуть синергетич-

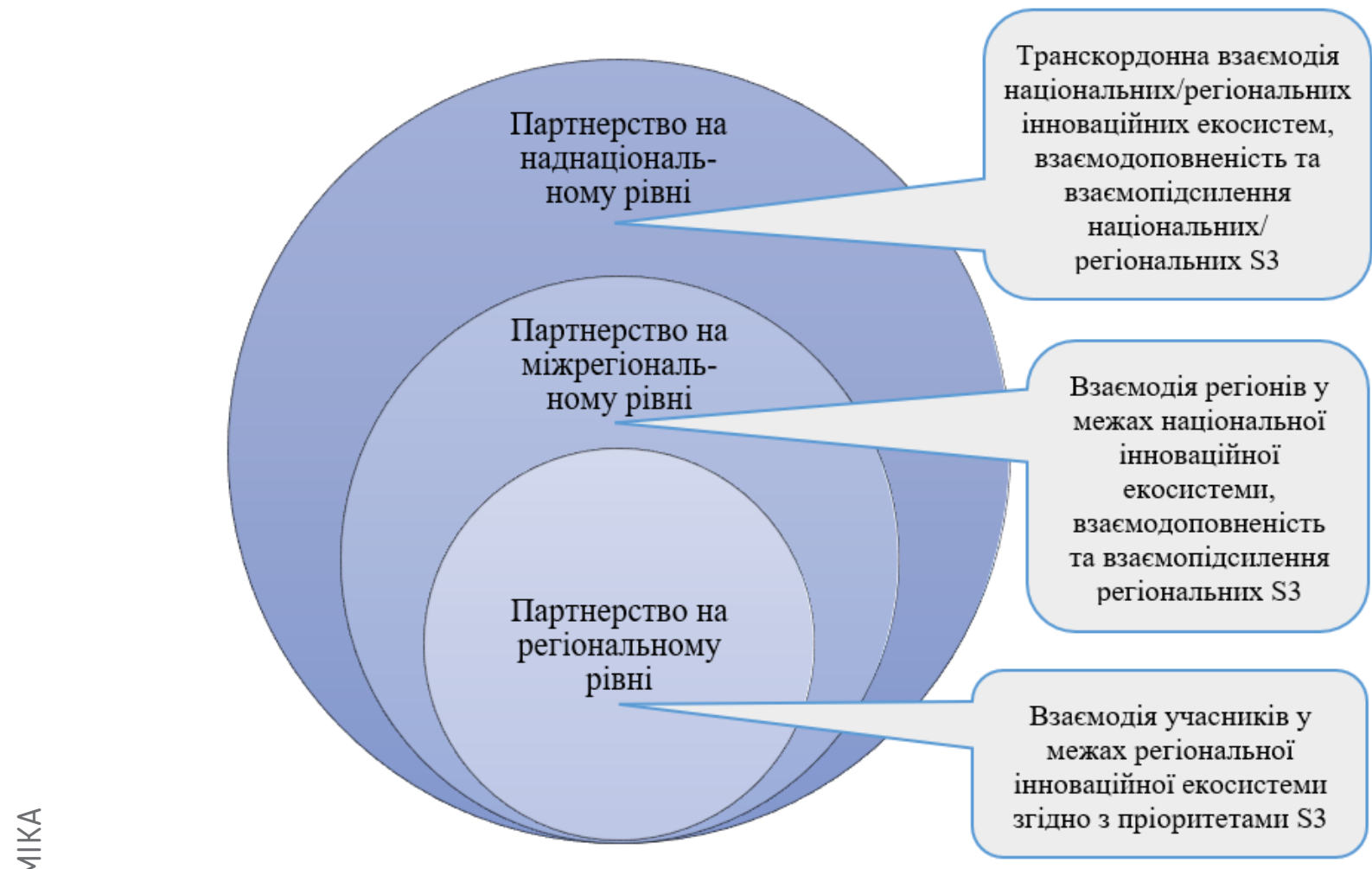

Рис. 1. Рівні партнерства в рамках концепції смартспеціалізації 


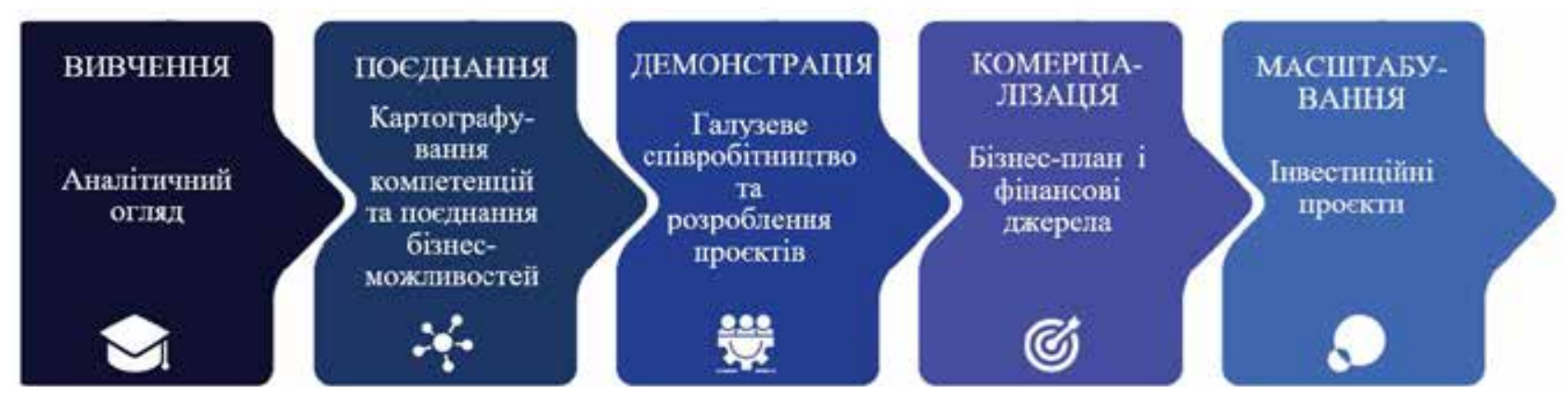

Рис. 2. Процес розвитку партнерства на основі тематичного підходу S3

Джерело: [19]

ної взаємодоповнюваності стратегій смартспеціалізації для розвитку промислових кластерів і досягнення світового лідерства. На основі досвіду цього співробітництва розроблено тематичний підхід S3, який передбачає п'ятиоразний процес створення та розвитку міжрегіонального партнерства (рис. 2).

Згідно з методологією розвитку тематичного міжрегіонального партнерства [19], кожна фраза вирішує свої завдання та поступово втілює наміри регіонів-претендентів започаткувати партнерську взаємодію. Так, спершу аналізуються ланцюги створення вартості, минулі та поточні проєкти співпраці, економічні зв'язки, стратегічні альянси за темою бажаного партнерства та розробляється аналітичний огляд, який містить бачення, місію, цілі, можливості міжрегіонального співробітництва в окремих copepax смартспеціалізації та відображає прояв зацікавленості і пропозицію партнерства. Сорормований на цьому етапі документ має проміжний характер та доопрацьовується у наступних фазах робочого процесу, поступово перетворюючись у повноцінний бізнесплан 3 визначеними фрінансовими джерелами і розробленими проєктами інвестування.

Співробітництво на основі тематичного підходу S3 націлено на сприяння підвищенню ефективності інноваційної політики ЄC та просуванню міжрегіонального співробітництва «в нові ланцюги створення вартості через кордони» [20]. Даний процес значно спрощується в умовах інтенсивного застосування цифрових технологій. Сучасні цифрові платформи, утворюючи інноваційні мережи, надають широкі і маловитратні можливості пошуку потенційних партнерів та організації комунікацій для розвитку науково-дослідної співпраці на національному та міжнародному рівнях [21; 22].

Єврокомісія розглядає онлайн-платформи як «драйвер зростання, інновацій і конку- ренції» [23]. Їх вважають не тільки зручним комунікаційним інструментом, а й «носієм стандартів (правил) організації» плідного співробітництва [24]. ЄС широко використовує сучасні цифрові технології для надання методологічної, організаційної, інорормаційної та інституційної підтримки різнорівневих суб'єктів, що прагнуть співпраці. Зокрема, такий супровід забезпечує платформа смартспеціалізації (S3 Platform), яка дозволяє налагоджувати зв'язки між регіонами Європи та інших країн світу.

Для організації взаємодії між регіонами Європи S3-платорорма пропонує три тематичні цифрові простори - Агропродовольчий (S3P-Agri-Food), Енергетичний (S3PEnergy) і Промислової модернізації (S3P-Industry) (табл. 2), які відповідають основним сорерам стратегічного зростання ЄС і активно підтримуються Європейською комісією [25]. Діяльність зазначених тематичних субплатформ спрямована на досягнення синергії як між секторами, так і між партнерствами.

За даними таблиці можна зробити висновок, що тематичні платформи утворюють сукупність інноваційних мереж, які поєднують пріоритети смартспеціалізації різних регіонів і зв'язують регіональні інноваційні екосистеми. Веб-простір S3 відкрито для залучення нових регіональних учасників, однак реалізація таких можливостей потребує детального ознайомлення з встановленими ЄС умовами партнерства.

Ураховуючи інноваційну спрямованість співробітництва у контексті смартспеціалізації та з часом зростаючу важливість забезпечення сталого розвитку регіонів, до переваг спільної діяльності також слід додати можливості, зазначені Ціллю сталого розвитку 17 «Партнерство для досягнення ЦСР» (SDG 17 - Partnership for the goals) [26], які трактуються таким чином: поєднання та опти- 
Характеристика тематичних платорорм

\begin{tabular}{|c|c|c|c|c|}
\hline $\begin{array}{l}\text { Тематична } \\
\text { платфрорма }\end{array}$ & $\begin{array}{c}\text { Тема міжрегіонального } \\
\text { партнерства }\end{array}$ & $\begin{array}{c}\text { Кількість } \\
\text { регіонів- } \\
\text { лідерів } \\
\end{array}$ & $\begin{array}{c}\text { Кількість } \\
\text { регіонів- } \\
\text { учасників }\end{array}$ & $\begin{array}{c}\text { Кількість } \\
\text { зацікавлених } \\
\text { регіонів }\end{array}$ \\
\hline \multirow{5}{*}{$\begin{array}{l}\text { Агропродовольча } \\
\text { (S3P-Agri-Food) }\end{array}$} & - Залучення споживачів & 2 & 2 & - \\
\hline & - Високотехнологічне землеробство & 1 & 32 & 2 \\
\hline & - Поживні інгредієнти & 2 & 7 & 5 \\
\hline & - Смартдатчики 4 Agrifood & 2 & 10 & 2 \\
\hline & - Відстежування і великі дані & 2 & 19 & 5 \\
\hline \multirow{6}{*}{$\begin{array}{l}\text { Енергетична } \\
\text { (S3PEnergy) }\end{array}$} & - Біоенергія & 2 & 3 & - \\
\hline & - Геотермальна енергія & 2 & 5 & 9 \\
\hline & - Морська відновлювальна енергія & 2 & 14 & - \\
\hline & - Розумні мережі & 2 & 8 & 17 \\
\hline & - Сонячна енергія & 2 & 9 & 2 \\
\hline & - Екологічні будівлі & 18 & 27 & 45 \\
\hline \multirow{24}{*}{$\begin{array}{l}\text { Промислова } \\
\text { модернізація } \\
\text { (S3P-Industry) }\end{array}$} & - ADMA Енергія & 2 & 11 & - \\
\hline & $\begin{array}{l}\text { - Сучасні матеріали для } \\
\text { акумуляторів }\end{array}$ & 3 & 9 & - \\
\hline & $\begin{array}{l}\text { - Штучний інтелект та людино- } \\
\text { машинний інтерфейс }\end{array}$ & 2 & 10 & 1 \\
\hline & - BERRY+ & 2 & 9 & - \\
\hline & - Біоекономіка & 2 & 23 & - \\
\hline & - Хімікати & 2 & 7 & 4 \\
\hline & $\begin{array}{l}\text { - Культурно-творчі регіональні } \\
\text { екосистеми }\end{array}$ & 3 & 12 & 3 \\
\hline & - Кібербезпека & 1 & 9 & 6 \\
\hline & $\begin{array}{l}\text { - Цисрровізація та безпека для } \\
\text { туризму }\end{array}$ & 3 & 5 & 3 \\
\hline & - Ефрективне та стале виробництво & 3 & 15 & 6 \\
\hline & $\begin{array}{l}\text { - Високопродуктивне виробництво } \\
\text { за допомогою 3D-друку } \\
\end{array}$ & 3 & 24 & 5 \\
\hline & - Водневі долини & 4 & 53 & 2 \\
\hline & - Медична техніка & 2 & 27 & - \\
\hline & - Гірничодобувна промисловість & 2 & 7 & - \\
\hline & $\begin{array}{l}\text { - Нові продукти на основі } \\
\text { нанотехнологій }\end{array}$ & 2 & 8 & - \\
\hline & - Персоналізована медицина & 3 & 8 & 1 \\
\hline & - Фотоніка & 1 & 16 & - \\
\hline & - Безпечна та стала мобільність & 2 & 9 & - \\
\hline & \begin{tabular}{|l|} 
- Розумні регіональні інвестиції в \\
текстильні інновації \\
\end{tabular} & 2 & 11 & 3 \\
\hline & \begin{tabular}{|l|} 
- Інтеграція малого та середнього \\
бізнесу в Індустрію 4.0 \\
\end{tabular} & 2 & 7 & 5 \\
\hline & - Соціальна економіка & 1 & 5 & - \\
\hline & - Спорт і життєва сила & 2 & 10 & 2 \\
\hline & - Водні розумні території & 3 & 19 & - \\
\hline & - Бездротові ІКТ & 2 & 9 & - \\
\hline
\end{tabular}


мізація використання наявних ресурсів через співпрацю на національному, субнаціональному та місцевому рівнях сприятиме реальним позитивним змінам в природному середовищі, суспільстві та економіці.

Для регіонів України розвиток європартнерства закладено обраним євроінтеграційним курсом та визначено в підписаній Угоді про асоціацію з ЄС [27], згідно з якою співробітництво передбачено, зокрема, у сферах:

- науки і технологій (глава 9) з метою наукового розвитку і зміцнення наукового потенціалу для вирішення національних та глобальних викликів (ст. 374);

- промислової й підприємницької політики (глава 10), у тому числі задля розвитку малого та середнього бізнесу, модернізації промисловості й удосконалення інноваційної політики через обмін знаннями, досвідом, розвиток кластерів та розширення доступу до фрінансових ресурсів (ст. 379).

Саме імплементація в практику регіонального управління підходу смартспеціалізації створює передумови для інтенсифрікації інтеграційних процесів та фрормування внутрішніх і зовнішніх умов для конкурентоспроможного розвитку України. У даному контексті особливе значення має сучасний етап приєднання вітчизняних науково-освітньої, інноваційної сфрер до європейського дослідницького простору. Результативність цього процесу залежатиме від фрормування комплексної державної політики щодо створення сприятливого середовища для розкриття потенціалу і розвитку регіональних інноваційних систем, які забезпечують розроблення та реалізацію стратегій смартспеціалізації [28].

Одним зі вагомих стимулів для вітчизняних суб'єктів освітньої, науково-дослідницької та інноваційної діяльності розвивати європартнерство на засадах смартспеціалізації $€$ отримання доступу до коштів структурних фрондів Європейського Союзу. У цьому питанні для правильного оцінювання перспектив України слід чітко розуміти сучасний підхід керівництва ЄС до орінансування інноваційних проєк- тів, у тому числі міжрегіонального/ транскордонного характеру.

Розвиток різних фрорм партнерства продиктовано певною мірою прагненням Єврокомісії підвищити конкурентоспроможність ЄС у глобальній економіці, мінімізувати дублювання, фррагментацію інноваційної діяльності, збільшити ії ефрективність 3 акцентом на ключові політичні пріоритети сталого розвитку та раціоналізувати використання коштів структурних фондів. Тому будь-які проєктні ініціативи розглядаються скрізь призму зазначених цілей, а смартспеціалізація використовується як інструмент їх досягнення.

Упровадження концепції S3 розвиває особливий вид конкуренції, зокрема між регіонами, а саме конкуренцію потенційного партнерства, яка буде посилюватися з поширенням імплементації даної концепції в економічно слабких країнах, що прагнуть європартнерства. За таких умов пропозиції від українських регіонів-претендентів мають бути конкурентоспроможними і відповідати сучасним вимогам до організації і управління інноваційно-інвестиційною діяльністю.

Висновки. Імплементація підходу смартспеціалізації сприяє інтеграції України до інноваційного простору ЄС завдяки розвитку партнерства на регіональному, міжрегіональному та наднаціональному рівнях, що супроводжується взаємодією інноваційних екосистем різного порядку та забезпечує взаємодоповненість і взаємопідсилення регіональних/національних стратегій смартспеціалізації. Даний процес відбувається в умовах активного впровадження цисррових технологій, поширення платформного партнерства і зростаючої конкуренції між потенційними партнерами за участь у спільних проєктах в рамках S3. За таких обставин українським регіонам слід ретельно аналізувати свої наявні конкурентні переваги та працювати над їх подальшим розвитком, що обов'язково має бути забезпечено сприятливим інституційним середовищем. Останнє визначає тематику наступного етапу дослідження.

\section{СПИСОК ВИКОРИСТАНИХ ДЖЕРЕЛ:}

1. Залознова Ю. С., Бутенко Н. В., Петрова І. П. Публічно-приватне партнерство в Україні: стан, проблеми та перспективи розвитку. Економічний вісник Донбасу. 2016. № 2(44). С. 21-28.

2. Драчук Ю. 3., Трушкіна Н. В. Реалізація механізму публічно-приватного партнерства в сфері інноваційного розвитку промисловості: світова практика. Науковий вісник ДДМА. № 1 (22Е). 2017. С. 148-154.

3. Залознова Ю. С., Петрова І. П. Режим міжнародно-публічно-приватного партнерства в науково-технічній та інноваційній сферах у контексті євроінтеграційних процесів. Управління економікою: теорія та практика. 2020. С. 19-31. DOI: https://doi.org/10.37405/2221-1187.2020.19-31 
4. Тютюнникова С. В., Фрідман О. А. Національна інноваційна система: сучасні тренди та виклики для України. Вісник Харківського національного університету імені В. Н. Каразіна. Серія: Міжнародні відносини. Економіка. Країнознавство. Туризм. 2020. Вип. 12. С. 224-232. DOI: https://doi.org/10.26565/2310-9513-2020-12-22

5. Сталий розвиток старопромислових регіонів України: інноваційний вимір : колективна монографія / 3 а ред. В. А. Омельяненка. Суми : Триторія, 2021. 298 с.

6. Гречана С. І., Рогозян Ю. С. Картографрічний метод у забезпеченні розвитку та співпраці об'єднаних територіальних громад. Економіка України. 2017. № 10(671). С. 65-74.

7. Рогозян Ю. С. Дискурсивний фррейм моніторингу реалізації домінантної стратегії розвитку міжрегіонального економічного співробітництва. Економіка та право. 2019. № 1(52). C 58-67. DOI: https://doi.org/10.15407/ econlaw.2019.01.058

8. Пітюлич М. М., Кудак К. М. Сучасні концепції місцевого розвитку в контексті партнерської співпраці у громадах. Економіка та суспільство. 2021. № 32. DOI: https://doi.org/10.32782/2524-0072/2021-32-95

9. Guide to Research and Innovation Strategies for Smart Specialisation (RIS 3) / D. Foray, J. Goddard, X. Goenaga Beldarrain et al. Luxembourg : Publications Office of the European Union, 2012. 122 p.

10. Shevtsova H., Shvets N., Kramchaninova M., Pchelynska H. In search of smart specialization to ensure the sustainable development of the post-conflict territory: the case of the Luhansk region in Ukraine. European Journal of Sustainable Development. 2020. V. 9 N. 2. P. 512-524. DOI: https://doi.org/10.14207/ejsd.2020.v9n2p512

11. Implementing Smart Specialisation: A Handbook / C. Gianelle, D. Kyriakou, C. Cohen and M. Przeor (eds). Brussels : European Commission, EUR 28053 EN, 2016. 122 p. DOI: https://doi.org/10.2791/610394

12. Rakhmatullin R., Hegyi F. B., Ciampi S. K., Gomez J., Mieszkowski K. Methodological Manual. Developing Thematic Interregional Partnerships for Smart Specialisation. A Practical Guide to Building and Managing Interregional Smart Specialisation Partnerships. EUR 30172 EN, Luxembourg : Office of the European Union, 2020.118 p. DOI: http://doi.org/10.2760/564759

13. Amosha A., Liashenko V., Pidorycheva I. Inter-regional and cross-border spaces in the context of smart specialization. Scientific Papers of Silesian University of Technology. Organization and Management Series. 2019. No 140. P. 7-16. DOI: http://doi.org/10.29119/1641-3466.2019.140.1

14. Петрова І. П. Модернізація економіки старопромислових регіонів на засадах smart-спеціалізації (за матеріалами наукового повідомлення на засіданні Президії НАН України 11 березня 2020 р.). Вісник Національної академії наук України. 2020. № 6. С. 30-37. DOI: https://doi.org/10.15407/visn2020.06.030

15. Pidorycheva I., Shevtsova H., Antonyuk V., Shvets N., Pchelynska H. A Conceptual Framework for Developing of Regional Innovation Ecosystems. European Journal of Sustainable Development. 2020. Vol. 9(3). P. 626-640. DOI: https://doi.org/10.14207/ejsd.2020.v9n3p626

16. Портал української мови та культури «Словник UA». URL: https://slovnyk.ua

17. Hassink R., Gong H. Six Critical Questions about Smart Specialization. European Planning Studies. 2019. Vol. 27(10). P. 2049-2065. DOI: https://doi.org/10.1080/09654313.2019.1650898

18. Our Story. Vanguard Initiative. URL: https://www.s3vanguardinitiative.eu/about/our-story/

19. Rakhmatullin R., Hegyi F. B., Ciampi S. K., Gomez J., and Mieszkowski K. Methodological Manual. Developing Thematic Interregional Partnerships for Smart Specialisation. A Practical Guide to Building and Managing Interregional Smart Specialisation Partnerships. EUR 30172 EN, Luxembourg : Office of the European Union, 2020. 118 p. DOI: http://doi.org/10.2760/564759

20. Communication from the Commission to the European Parliament, the Council, the European Economic and Social Committee, and the Committee of the Regions Strengthening Innovation in Europe's Regions: Strategies for resilient, inclusive, and sustainable growth. URL: https://op.europa.eu/en/publication-detail/-/ publication/785a2da5-6b9e-11e7-b2f2-01aa75ed71a1/language-en

21. Шевцова Г. 3., Омельяненко В. А., Прокопенко О. В. Концептуальні питання цифровізації інноваційних мереж. Економіка промисловості. 2020. № 4(92). C. 67-90. DOI: http://doi.org/10.15407/econindustry 2020.04.067

22. Omelyanenko V., Kudrina O., Shevtsova H., Prokopenko O., Petrenko V. ICT for Innovative Education and Science: Smart Environment for Networked Strategies. 2020 43nd International Convention on Information, Communication and Electronic Technology (MIPRO). 2020. P. 727-730. DOI: http://doi.org/10.23919/MIPRO48935. 2020.9245133

23. Online Platforms and the Digital Single Market Opportunities and Challenges for Europe. European Commission. Brussels, April 2016. URL: https://publications.parliament.uk/pa/ld201516/ldselect//deucom/129/ 12902.htm (дата звернення: 25.11.2021).

24. Вишневський О. С. Цифрова платформізація процесу стратегування розвитку національної економіки : монографрія. Київ : Ін-т економіки пром-сті НАН України, 2021. 449 с. 
25. S3 Thematic Platforms. Smart Specialisation Platform. URL: https://s3platform.jrc.ec.europa.eu/s3-thematicplatforms

26. The SDG Partnership Guidebook: A practical guide to building highimpact multi-stakeholder partnerships for the Sustainable Development Goals, Darian Stibbe and Dave Prescott, The Partnering Initiative and UNDESA 2020. URL: https://sdgs.un.org/publications/sdg-partnership-guidebook-24566

27. Угода про асоціацію між Україною та ЄС. Євроінтеграційний портал. URL: https://eu-ua.kmu.gov.ua/ tekst-uhody-pro-asotsiatsiiu

28. Швець Н. В. Обмеження і можливості науково-освітньої та інноваційної ссрер України в контексті фрормування регіональних смарт-спеціалізацій. Економіка та право. 2021. № 4(63). С. 112-122. DOI: https://doi.org/ 10.15407/econlaw.2021.04.112

\section{REFERENCES:}

1. Zaloznova, Yu., Butenko, N. \& Petrova, I. (2016) Publichno-pryvatne partnerstvo v Ukraini: stan, problemy ta perspektyvy rozvytku [Publicprivate partnership in Ukraine: state, problems and prospects of the development]. Ekonomichnyi visnyk Donbasu Economic - Herald of the Donbas, 2(44), 21-28. (in Ukrainian)

2. Drachuk, Yu. \& Trushkina, N. (2017) Realizatsiia mekhanizmu publichno-pryvatnoho partnerstva v sferi innovatsiinoho ozvytku promyslovosti: svitova praktyka. Naukovyi visnyk DDMA, 1(22E), 148-154. (in Ukrainian)

3. Zaloznova, Yu. \& Petrova, I. (2020) Rezhym mizhnarodno-publichno-pryvatnoho partnerstva v naukovo-tekhnichnii ta innovatsiinii sferakh u konteksti yevrointehratsiinykh protsesiv. Upravlinnia ekonomikoiu: teoriia ta praktyka, 19-31. DOI: https://doi.org/10.37405/2221-1187.2020.19-31 (in Ukrainian)

4. Tiutiunnykova, S. \& Fridman, O. (2020) Natsionalna innovatsiina systema: suchasni trendy ta vyklyky dlia Ukrainy [National innovation system: current trends and challenges for Ukraine]. Visnyk Kharkivskoho natsionalnoho universytetu imeni V. N. Karazina. Seriia: Mizhnarodni vidnosyny. Ekonomika. Krainoznavstvo. Turyzm - International Relations. Economics. Country Studies. Tourism, 12, 224-232. DOI: https://doi.org/10.26565/2310-95132020-12-22 (in Ukrainian)

5. Omelianenka, V. A. (Ed.) (2021) Stalyi rozvytok staropromyslovykh rehioniv Ukrainy: innovatsiinyi vymir: kolektyvna monohrafiia. Sumy: Trytoriia. (in Ukrainian)

6. Hrechana, S. I. \& Rohozian, Yu. S. (2017) Kartohrafichnyi metod u zabezpechenni rozvytku ta spivpratsi obiednanykh terytorialnykh hromad [Cartographic method to ensure development and cooperation of united territorial communities]. Ekonomika Ukrainy - Economy of Ukraine, 10(671), 65-74. (in Ukrainian)

7. Rohozian, Yu. S. (2019) Dyskursyvnyi freim monitorynhu realizatsii dominantnoi stratehii rozvytku mizhrehionalnoho ekonomichnoho spivrobitnytstva [Discourse frame for monitoring implementation of the dominant strategy for interregional economic collaboration development]. Ekonomika ta parvo - Economics and Law, 1(52), 58-67. DOI: https://doi.org/10.15407/econlaw.2019.01.058 (in Ukrainian)

8. Pityulych, M. \& Kudak, K. (2021) Suchasni kontseptsii mistsevoho rozvytku v konteksti partnerskoi spivpratsi $\mathrm{u}$ hromadakh [Modern concepts of local development in the context of partnership in communities]. Ekonomika ta suspilstvo - Economy and Society, 32. DOI: https://doi.org/10.32782/2524-0072/2021-32-95 (in Ukrainian)

9. Foray, D., Goddard, J. \& Goenaga Beldarrain X., et al. (2012) Guide to Research and Innovation Strategies for Smart Specialisation (RIS 3). Luxembourg: Publications Office of the European Union.

10. Shevtsova, H., Shvets, N., Kramchaninova, M., Pchelynska, H. (2020) In search of smart specialization to ensure the sustainable development of the post-conflict territory: the case of the Luhansk region in Ukraine. European Journal of Sustainable Development, 9(2), 512-524. DOI: https://doi.org/10.14207/ejsd.2020.v9n2p512

11. Gianelle, C., Kyriakou, D., Cohen C. \& Przeor M. (Eds.) (2016) Implementing Smart Specialisation: A Handbook. Brussels: European Commission. DOI: https://doi.org/10.2791/610394

12. Rakhmatullin, R., Hegyi, F. B., Ciampi, S. K., Gomez J. \& Mieszkowski K. (2020) Methodological Manual. Developing Thematic Interregional Partnerships for Smart Specialisation. A Practical Guide to Building and Managing Interregional Smart Specialisation Partnerships. Luxembourg: Office of the European Union. DOI: https://doi.org/10.2760/564759

13. Amosha, A., Liashenko, V., Pidorycheva, I. (2019) Inter-regional and cross-border spaces in the context of smart specialization. Scientific Papers of Silesian University of Technology. Organization and Management Series, 140, 7-16. DOI: https://doi.org/10.29119/1641-3466.2019.140.1

14. Petrova, I. P. (2020) Modernizatsiia ekonomiky staropromyslovykh rehioniv na zasadakh smart-spetsializatsii [Modernization of the economy of the old industrial regions on the basis of smart specialization]. Visnyk Natsionalnoi akademii nauk Ukrainy - Herald of National Academy of Sciences of Ukraine, 6, 30-37. DOI: https://doi.org/ 10.15407/visn2020.06.030 (in Ukrainian) 
15. Pidorycheva, I., Shevtsova, H., Antonyuk, V., Shvets, N. \& Pchelynska H. A (2020) Conceptual Framework for Developing of Regional Innovation Ecosystems. European Journal of Sustainable Development, 9(3), 626-640. DOI: https://doi.org/10.14207/ejsd.2020.v9n3p626

16. Portal ukrainskoi movy ta kultury «Slovnyk UA». Retrieved from: https://slovnyk.ua (in Ukrainian)

17. Hassink, R. \& Gong, H. (2019) Six Critical Questions about Smart Specialization. European Planning Studies, 27(10), 2049-2065. DOI: https://doi.org/10.1080/09654313.2019.1650898

18. Our Story. Vanguard Initiative. Retrieved from: https://www.s3vanguardinitiative.eu/about/our-story/

19. Rakhmatullin, R., Hegyi, F. B., Ciampi, S. K., Gomez, J., \& Mieszkowski K. (2020) Methodological Manual. Developing Thematic Interregional Partnerships for Smart Specialisation. A Practical Guide to Building and Managing Interregional Smart Specialisation Partnerships. Luxembourg: Office of the European Union. DOI: https://doi.org/10.2760/564759

20. Communication from the Commission to the European Parliament, the Council, the European Economic and Social Committee, and the Committee of the Regions Strengthening Innovation in Europe's Regions: Strategies for resilient, inclusive, and sustainable growth. Retrieved from: https://op.europa.eu/en/publication-detail/-/ publication/785a2da5-6b9e-11e7-b2f2-01aa75ed71a1/language-en

21. Shevtsova, H. Z., Omelyanenko, V. A., \& Prokopenko, O. V. (2020) Kontseptualni pytannia tsyfrovizatsii innovatsiinykh merezh [Conceptual issues of innovation networks digitalization]. Ekonomika promyslovosti - Economy of Industry, 4(92), 67-90. DOI: https://doi.org/10.15407/econindustry2020.04.067 (in Ukrainian)

22. Omelyanenko, V., Kudrina, O., Shevtsova, H., Prokopenko, O. \& Petrenko V. (2020) ICT for Innovative Education and Science: Smart Environment for Networked Strategies. 2020 43nd International Convention on Information, Communication and Electronic Technology (MIPRO), 727-730. DOI: https://doi.org/10.23919/ MIPRO48935.2020.9245133

23. Online Platforms and the Digital Single Market Opportunities and Challenges for Europe. European Commission. Brussels. Retrieved from: https://publications.parliament.uk/pa/ld201516/ldselect//deucom/129/12902.htm

24. Vyshnevskyi, O. S. (2021) Tsyfrova platformizatsiia protsesu stratehuvannia rozvytku natsionalnoi ekonomiky: monohrafiia. Kyiv: In-t ekonomiky prom-sti NAN Ukrainy. (in Ukrainian)

25. S3 Thematic Platforms. Smart Specialisation Platform. Retrieved from: https://s3platform.jrc.ec.europa.eu/ s3-thematic-platforms

26. The SDG Partnership Guidebook: A practical guide to building highimpact multi-stakeholder partnerships for the Sustainable Development Goals, Darian Stibbe and Dave Prescott, The Partnering Initiative and UNDESA 2020. Retrieved from: https://sdgs.un.org/publications/sdg-partnership-guidebook-24566

27. Uhoda pro asotsiatsiiu mizh Ukrainoiu ta YeS. Yevrointehratsiinyi portal. Retrieved from: https://eu-ua.kmu.gov.ua/tekst-uhody-pro-asotsiatsiiu

28. Shvets, N. V. (2021). Obmezhennia i mozhlyvosti naukovo-osvitnoi ta innovatsiinoi sfer Ukrainy v konteksti formuvannia rehionalnykh smart-spetsializatsii [Limitations and opportunities of scientific educational and innovative spheres of ukraine in the context of the formation of regional smart specialisations]. Ekonomika ta parvo - Economics and Law, 4(63), 112-122. DOI: https://doi.org/10.15407/econlaw.2021.04.112 (in Ukrainian) 